\title{
Hypertrophic osteoarthropathy and congenital heart disease: this is not casual
}

\author{
Ester Ferreira, Isabel Camões
}

Internal Medicine Department, Centro Hospitalar de São João, Porto, Portugal

Correspondence to Dr Ester Ferreira, esterferreira28@gmail.com
To cite: Ferreira $\mathrm{E}$ Camões I. BMJ Case Rep Published online: [please include Day Month Year] doi:10.1136/bcr-2013009392

\section{SUMMARY}

This case presents a patient with congenital cyanotic heart disease in whom secondary hypertrophic osteoarthropathy was diagnosed. The symptoms of severe bilateral leg pain started 2 months before hospital admission. The presence of clubbing, painful swelling of the lower limbs and his comorbid condition roused the suspicion of hypertrophic osteoarthropathy and a skeleton radiograph of the lower limbs was performed. The last showed changes consistent with periosteal new bone formation, so a non-steroid anti-inflammatory drug was started with complete resolution of the debilitating pain. Hypertrophic osteoarthropathy is an uncommon disease that may be genetically acquired or secondary to other conditions affecting lungs, heart, liver or bowel.

Considering it elusive pathogenesis, treatment options are scarce and symptomatic relief is still the main objective.

\section{BACKGROUND}

The association of clubbing and arthritis, with chronic lung and heart disease, was initially observed by Von Bamburger, in Vienna, in 1889 and Marie, in Paris, in 1890, so this condition is also known as Pierre Marie-Bamberger syndrome. ${ }^{1}$

This syndrome may be classified as primary, also known as pachydermoperiostitis, a rare familial disorder, or secondary to other extrathoracic and intrathoracic diseases.

However frequently forgotten secondary hypertrophic osteoarthropathy (HOA) is not so unusual condition. Its association with heart and lung disease is well established and a low index of suspicion is essential for diagnostic purposes.

Now, several image studies can be used to support the clinical suspicion; nevertheless, giving the high availability, cost-effectiveness and great sensitivity, bone radiograph persists as a good tool to confirm the diagnosis.

\section{CASE PRESENTATION}

A 17-year-old man with congenital pulmonary atresia and interventricular communication was admitted with fever, abdominal cramps and watery diarrhoea since 4 days. Besides those symptoms, the patient also referred persistent lower limbs pain, which started 2 months ago, and painful swollen knees and ankles in the last month.

On physical examination he was haemodynamically stable; his breath rate was $36 / \mathrm{min}$ and oxygen saturation (on room air) was $80 \%$. Central cyanosis was present and jugular venous pressure had $8 \mathrm{~cm}$ at $30^{\circ}$. A systolic heart murmur was detected on the left sternum border and respiratory sounds were clear. A tender $3 \mathrm{~cm}$ hepatomegaly was found. Fingers and toes showed clubbing and the anterior surface of the tibias, knees and ankles were painful on palpation. The findings of the remainder physical examination were normal.

\section{INVESTIGATIONS}

A laboratory evaluation showed an elevated $\mathrm{C}$ reactive protein $(120 \mathrm{mg} / \mathrm{L})$ without leucocytosis and a normal liver and kidney function test. Rheumatoid factor and antinuclear antibodies were negative, as were cytomegalovirus IgM, parvovirus IgM, Wright and Widal reactions.

Stools were collected for microbiological analyses and Clostridium difficile toxin test, after which ciprofloxacin was started, considering the high probability of acute infectious gastroenteritis.

As a result the diarrhoea improved and his $\mathrm{C}$ reactive protein returned to normal values within 3 days. Stool analyses were negative. Despite an improvement in gastrointestinal symptoms, the patient's musculoskeletal discomforts persisted. A skeletal radiograph was performed to the lower limbs and showed lamellar periosteal new bone formation around the upper (figure 1A) and lower (figure 1B) shafts of the tibias and fibulas bones (an opaque line of new bone formation separated from the underlying cortex by a narrow radiolucent band).

Given the presence of cyanotic congenital heart disease and the radiological findings the diagnosis of secondary HOA was presumed.

\section{TREATMENT}

Ibuprofen $400 \mathrm{mg}$ three times in day was started and pain relief obtained.

\section{OUTCOME AND FOLLOW-UP}

HOA symptoms had remitted with only nonsteroid anti-inflammatory drugs (NSAID) supportive treatment and the patient was discharged home.

\section{DISCUSSION}

The diagnosis of the complete form of HOA is usually based on the triad of digital clubbing, periostitis of the tubular bones and painful swelling of limbs. These changes are more frequent in the lower extremities and non-inflammatory arthritis often occurs in the large joints in a bilateral and symmetrical fashion $^{1}$ as observed in the present case. Its occurrence in patients with congenital heart disease seems to be high, affecting up to $31 \%$ of them, as showed by Martinez-Lavín et $a l^{2}$ some decades ago. 


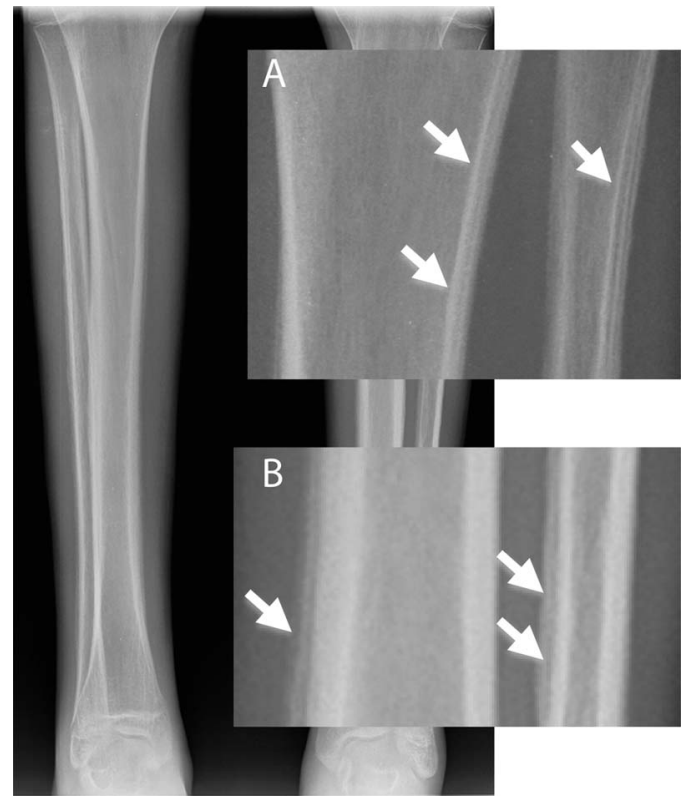

Figure 1 Radiograph of the legs revealing the periosteal new bone formation (white arrows) along the upper (A) and lower (B) shafts of the tibia and fibula. Image sent by Radiology Department of Centro Hospitalar de São João, Porto, Portugal.

Despite being known for over 100 years, the pathogenesis of HOA has not yet been elucidated and treatment options for this condition are under investigation. Until now, treatment has included management of the underling cause, if possible, and symptoms relief with NSAID and other conventional analgesic therapies. $^{3}$ In cases refractory to conventional analgesics, pamidronate $1 \mathrm{mg} / \mathrm{kg}$ intravenously (or $60 \mathrm{mg}$ total) has been tried with good results. 4

\section{Learning points}

- Hypertrophic osteoarthropathy (HOA) is a syndrome of digital clubbing, periostitis of the tubular bones and painful swelling of limbs.

- One-third of the patients with congenital heart disease are affected by HOA.

- Analgesic therapies, namely non-steroid anti-inflammatory drugs, are the mainstay of the treatment of HOA.

Contributors FE identified and managed the case and drafted the paper. $\mathrm{Cl}$ drafted the paper.

\section{Competing interests None.}

Patient consent Obtained.

Provenance and peer review Not commissioned; externally peer reviewed.

\section{REFERENCES}

1 Martinez-Lavin M, Matucci-Cerinic M, Jajic I, et al. Hypertrophic osteoarthropathy: consensus on its definition, classification, assessment and diagnostic criteria. J Rheumatol 1993:8:1386-7.

2 Martinez-Lavin M, Bobadilla M, Casanova J, et al. Hypertrophic osteoarthropathy in cyanotic congenital heart disease: its prevalence and relationship to bypass of the lung. Arthritis Rheum 1982;10:1186-93.

3 Nguyen S, Hojjati M. Review of current therapies for secondary hypertrophic pulmonary osteoarthropathy. Clin Rheumatol 2011;1:7-13.

4 Amital H, Applbaum YH, Vasiliev L, et al. Hypertrophic pulmonary osteoarthropathy: control of pain and symptoms with pamidronate. Clin Rheumatol 2004;4:330-2.

Copyright 2013 BMJ Publishing Group. All rights reserved. For permission to reuse any of this content visit

http://group.bmj.com/group/rights-licensing/permissions.

BMJ Case Report Fellows may re-use this article for personal use and teaching without any further permission.

Become a Fellow of BMJ Case Reports today and you can:

- Submit as many cases as you like

- Enjoy fast sympathetic peer review and rapid publication of accepted articles

- Access all the published articles

- Re-use any of the published material for personal use and teaching without further permission

For information on Institutional Fellowships contact consortiasales@bmjgroup.com

Visit casereports.bmj.com for more articles like this and to become a Fellow 